- miért vonzotta a kutatókat. Ugyanis a hosszútávon is változatlan területi-ökonómiai szociális egység itt már eleve adott volt. Ter. mészetesen ugyanez vonatkozik a kapitalista-kori nagybirtok-üzemekre, az uradalmakra is. Itt azonban csak egy-egy uradalom tör . ténetét felvázoló tanulmány látott napvilágot, jóllehet TÓTH TIBOR definiciója alapján a nagybirtok-üzemek szintézisét is meg lehetne irni. Persze a megoldást nehezíti az a tény, hogy régió alatt a történészek összefüggö nagyobb földrajzi egységet értenek, véleményem szerint ezt az álláspontot kellene felülvizsgálni és a térbeliséget az egyéb vizsgálati szempontoknak kellene alárendelni. Nem véletlen miként azt a szerzó is írja, hogy az angolszászirodalomban pl. ,a geográfiában, amelynek legrégibb tapasztalatai vannak a regionális elemzés területén, több mint egy év. tizede fokozatos eltávolodás figyelhetó meg a régiótól, mint alapvetó külön egységtól és koncepciótól". Természetesen ez nem jelentheti azt, hogy a térbeli vizsgálatot negligáljuk, mivel éppen a várostörténeti kutatásoknál láthatjuk - a szerzó tanulmányában ezt plasztikusan érzékelteti -, hogy a városok fejlödésében milyen alapvetö eltérések mutatkoznak. FÜR LAJOS szerint, ,a 19. század végétól a Duna-Tisza köze kertkulturális tanyarendszere egészen sajátos gazda- sági és társadalmi képzódmény, mozaikszerü történeti táj". Ugyanezt elmondhatjuk a dunántúli uradalmakra is, a városokra azonban ez kevésbé vonatkozik.

TIMÁR LAJOS tanulmányában a hazai és a nemzetközi szakirodalmat egyaránt beépi$t i$, elemzi, ha kell vitatkozik, végezetül pedig saját álláspontját is közli. Munkája azonban nem csupán teoretikus jellegü, hanem azt olyan alapkutatásnak tekinthetjük, amelyet a gyakorlati szakemberek a települések fejlesztésénél felhasználhatnak. Még ma is aktuális ERDEI FERENC-nek az 1930-as évek végén tett megállapitása, hogy nagyobb vidékek városok hiányában az országos fejlơdés ütemétól elmaradnak. De a fenti megállapításnak az ellentét párja is igaz, amely szerint az iparosodó városok továbbfejlödésének egyik fó akadálya, ha azt a vonzáskörzete harmonikusan nem egésziti ki. Napjainkban ez a veszély egyre inkább aktuális.

úgy gondolom, hogy a tanulmány nemcsak a történészek számára lesz iránymutató, hanem mindazoknak, akik a települések fejlesztésével és a távlati tervek készítésével foglalkoznak. Éppen ezért ajánlom e tanulmányt mindazoknak, akik munkájukat felelósséggel kívánják végezni.

\section{SZILI FERENC}

\title{
BOKOR ÁGNES: SZEGÉNYSÉG A MAI MAGYARORSZÁGON
}

(Magvetö Kiadó, Budapest, 1987. p. 280)

A Gyorsuló idó sorozat - amelynek tartalmát a tudomány éppen elótérben álló prob. lémái, nemrég megválaszolt és a közeljövóben megválaszolandó kérdései befolyásolják leginkább - új kötettel gazdagitotta a szegénység problémakörét vizsgáló tanulmányok sorát.

Bokor Ágnes könyve amellett, hogy a mai magyar társadalom egy - sok szempontból megrendító - metszete, egyben nagyszabású ki. sérlet is: a természettudományos megismerés egzaktságát közelí tő szociológiai eszközrendszer felé vezetó út keresése.

A szegénység történelmileg állandóan változó jelenség. Egy szempontból azonban min- dig azonos marad: ,... egy adott társadalom legrosszabb helyzetben lévó tagjai a mindenkori szegények. Hogy ez konkrétan mit jelent, az mindig az adott társadalom fejlettségi szintjétöl függ." A szerzó éppen ezért fontosnak tartja a nincstelenséggel jellemezhetó ."klasszikus"' szegénység és a modern társadalmakra jellemzó, „depriváció" fogalmi elkülönitését. Tény, hogy a tudományos és politikai nyelvben sokszor kínosan ügyelnek, nehogy a "szegénység" szó nemkivánatos asszociációkat keltsen. Talán ezért hallunk egyre többet „hátrányos helyzetü" vagy ,halmozottan hátrányos helyzetü" rétegekről, csoportok- 
ról. Viták folynak a szegénység lehetséges értelmezéséról, tartalmáról is. Bokor Ágnes számára azonban az idegen hangzású kifejezés nem kibúvó a problémák nyílt megfogalmazása alól. A társadalmi fejlődés folyamán - véleménye szerint - a szegénységnek ez az új formája jelenik meg és válik dominánssá. Akkor, amikor a társadalmi-gazdasági fejlettség már eléri azt a szintet ,...., amelyen lehetóvé válik a hierarchikus struktúrában minden szempontból alul lévők elemi szükségleteinek kielégí tése.

... A deprivációt a szegénység korábbi formájától éppen az különbözteti meg, hogy ebben már nem az alapvetó javaktól való megfosztottság dominál. Egyezó vonás viszont az, hogy az elsódieges szükségleteken túli anyagi javak, illetve a szimbolikus javak hozzáférhetetlensége továbbra is fennáll."

A fenti meghatározás kulcskérdése - a szerzó szerint - érezhetóen az: mit értünk „elsődleges", „elemi" szükségleten. Mivel lehetetlen erre a fogalomra pontos és kimerító definiciót adni, Bokor MARSHALL koncepcióját követi: a többség számára kielégíthetó szükségletekkel azonositja a most érvényes „alapszükségleteket".

A könyvben megfogalmazott gondolatok elsó pillantásra meglehetósen pesszimistán közelítenek e jelentós társadalmi problémához, hiszen ,.... a hierarchikusan tagolt társadalmakban az alul lévök mindig szegények, illetve depriváltak a többiekhez képest."

"De miért éppen azok a szegények akik?" és „Milyen értelemben nevezhetók szegényeknek?" Ez a két kérdés, amely meghatározó a társadalmi lehetóségek elosztásánál hátrányba került emberek szempontjából, áll a vizsgálat fókuszában. Az, hogy egy adott társadalomban még hagyományos szegénységról, vagy „már" deprivációról beszélünk-e, két tényezón múlik. Az egyik az, hogy az adott társadalom, ország egésze szegénynek számít-e más társadalmakhoz viszonyitva, a másik pedig az, hogy az adott országon belül a lakosság többségét vagy kisebbségét alkotják-e a szegények. Bokor Ágnes rámutat, hogy a depriváció ma még kevéssé kikristályosodott formában, néhol a hagyományos szegénység jellemzóit is hordozva létezik nálunk.

Egy még nem tökéletesen kialakult társadalmi jelenség és a neki megfelelö csoport kutatása bonyolult feladat, hiszen a jelenség vizsgálatához ismerni kellene a csoport hatá- rait, ehhez viszont a jelenséget kellene a lehetó legmélyebben ismerni. A kutatási probléma természete tehát megköveteli egy olyan közelítéses eljárási mód alkalmazását, amely - matematikai hasonlattal élve - egy kétismeretlenes egyenletre hasonlit. $A z$ egyik ismeretlent mindig ismertnek tételezve fel, számítja ki a másikat, majd ennek segítségével egy jobb becslést készít az elsó ismeretlenre, és így tovább. Igazából senki sem tudja megmondani, hogyan lehet jelenségeket úgy leegyszerüsíteni, hogy azok lényege ne változzék meg, ugyanakkor kvantitativ kezelésük lehetövé váljon. $A z$ a tényanyag azonban - amit a Társadalomtudományi Intézet egyik kutatási programjának széles körü felmérése szolgáltatott e munka megírásához - részletes és - úgy tünik - megbízható adatbázist nyújt a depriváció és a társadalmi munkamegosztás közötti összefüggések, az életstílus és az életkörülmények egymásra hatása, a közrejátszó demográfiai, regionảiss és mobilitási tényezók kimutatásához.

Bokor Agnes olyan - társadalmilag releváns - dimenziókat választott, amelyek empirikus mérésére lehetősége nyilt. E dimenziók egymás mellé állításával - mint mozaikot tartja elénk társadalmunk ,alulnézetü" tükrét. $S$ hogy mit mutat ez a „tükör"? A felmérési eredmények alapján a magyarországi szegények - illetve depriváltak - számát minimálisan másfél millióra becsülhetjük, bár a szerzó hangsúlyozza, hogy a hagyományos szegénység csak „szigetesnek" nevezhető formában lelhetó fel (pl. cigány telepek).

A demográfiai és települési viszonyok ha tását a munka és életfeltételek elosztására elsóként és más jelenségektól elkülönítetten tárgyalja. „Az emberek különböző életkorúak, különbözó számú utódot hoznak világra, különbözó lélekszámú településeken tömörülnek - ezek a természetes különbségek azonban társadalmi egyenlötlenségekké lesznek azáltal, hogy bizonyos életkori csoportok, bizonyos fajta családok vagy bizonyos települések lakói a „gyengébb érdek" megtestesítói a javak és prioritások elosztása körüli érdekkonflikt usokban.

Következtetései alátámasztják azt a hipotézist, miszerint a lakóhely, mind szüken, a család mozgásterét jellemezve, mind tágabban, beleértve a településközösséget és annak településhálózaton belüli helyét is, megha tározó az egyén társadalmi helyzetére. Rész 
letes képet rajzol a depriválódás valószinüségének területi megoszlásáról, kiemelve, hogy az Alföld lakóinak van erre legnagyobb esélyük.

Szociológiai megközelítésmódja miatt természetesen nem szán és nem is szánhat nagyobb szerepet a depriváció bemutatásában a települési viszonyoknak mint példáui a demográfiai tényezóknek. Ez a közelítésmód ugyanakkor annyira kézzel fogható, mindennapi életben tapasztalható ,kivánatos és nem kivánatos doigok" világos elkülöníthetơségén alapszik, hogy szinte láttatja, érezteti az olvasóval: milyen érzés lehet a „minden szempontból lemaradottak" bórében lenni. De célja nemcsak ez. A tapasztalatok összegzéseként egy leegyszerúsített társadalmi modellt is felvázol.

.... ha konkrét jelentésüktól megfosztva, csak lényegükre lecsupaszítva tekintjük az emberek társadalmi helyzetére jeliemzö számtalan vonást, vagyis csupán azt vesszük figyelembe, hogy azok elónyösek, hátrányosak vagy indifferensek, akkor ebból a távolságból csupán három társadalmi aggregátum: a privilegizáltak, a középen lévök és a depriváltak csoportja vehetó ki." A csoportokat elválasztó két nagy ".törésvonal" közül az elónyös helyzetüek és a többséget magában foglaló társadalmi csoport között húzódó szélesebb és mélyebb, mint amekkora a depriváltakat a középen lévóktól elválasztja. A hátránymentesség - Bokor Ágnes szerint - nem átlag körüli, hanem elónyös helyzetet teremt, hiszen a társadalom többségének legalább egy-két szempontból hátrányai is vannak. Felhívja figyelmünket arra is, hogy a depriváltak csoportjával szinte azonos körülmények között éló „veszélyeztetetteket” csupán az különbözteti meg az elóbbiektól, hogy kivételes eró. feszitéseket tesznek társadalmi helyzetük javitása érdekében. Ezt, rendkívül sok munkával és fokozott konformitással, lojalitással gondolják elérni. A rétegzódési és mobilitási vizsgálatok ugyanakkor azt mutatják, hogy a depriváltak - mindenköri körülményeik miatt kevésbé tudnak az éppen napirenden lévó társadaimi folyamatokhoz csatlakozni, kevésbé képesek „megérteni az idók szavát”.

Azt tehát, hogy mit jelent ma szegénynek lenni Magyarországon - mint azt az ötletes könyvborító hátlapján igéri - Bokor Ágnes rendkíuül impressziv láttató eróvel és tudományos precízitással mutatja be. A szomorú összképet nem javítja az az optimistának túnó kicsengés sem, miszerint .... az elmúlt 15-20 év fejleményei megalapozták azt a reményt, hogy a magyar társadalmi és politikai stuktúra képes megszerezni a folyamatos megújulás képességét, s ezáltal a szegénység elveszítheti jelenlegi társadalmi funkcióit".

A ma valós területi-társadalmi problémáinak helyes értelmezéséhez alapvetó gondolatokkal járul hozzá, ezért ajánlom minden érdeklơdó polcára a könyvet.

KERESZTES NAGY CSILLA

\section{NEMZETKÖZI HATÁSOK A SZOCIALISTA ORSZÁGOK TERÜLETI STRUKTÚRÁJÁRA}

„Internationale Einflüsse auf die Territorialstruktur Sozialistischer Länder. Teil 1. Red.: Hellmut Harke. - Marton Luther Universităt Halle.Wittenberg, Wissenschaftliche Beiträge 1985/17 Halle."

A szocialista országok felsöfokú földrajzot oktatóinak nemzetközi szemináriumsorozata 1976-ban a Lomonoszov Egyetem kezdeményezésére indult, és minden évben más európai KGST országban rendezték meg (Románia nélkül). Az 1970-es évek második felében a környezetváltozás, az urbanizáció, a mezó- 